\title{
Efficacy of Islamic Wet Cupping Therapy on Vital Sign in Lunar Phase: A Comparative Study Between Sunnah and Non-sunnah Dates
}

\author{
Syahruramdhani Syahruramdhani ${ }^{1, *}$ Nurvita Risdiana ${ }^{2}$ Aris Setyawan $^{3}$ \\ ${ }^{1,2}$ School of Nursing, Faculty of Medicine and Health Sciences, Universitas Muhammadiyah Yogyakarta, Indonesia \\ ${ }^{3}$ School of Nursing, Institute of Health Science, Surya Global Yogyakarta, Indonesia \\ *Corresponding author. Email: syahruramdhani@umy.ac.id
}

\begin{abstract}
Introduction: Cupping therapy is a skin vacuuming method for releasing accumulated toxins and oxidants in the body. Cupping therapy is believed as a treatment for several diseases such as hypertension, migraine, carpal tunnel syndrome, and it also takes part in stroke rehabilitation treatment. Based on Prophet Muhammad (PBUH) 's hadith, the best time for doing cupping therapy is after the full moon phase, which is $17^{\text {th }}, 19^{\text {th }}$, and $21^{\text {st }}$ in the Islamic calendar or called sunnah dates. Aim: This study aims to compare cupping therapy's efficacy on vital signs in sunnah and non-sunnah dates. Method: This study used a quantitative method with a quasi-experiment approach. Thirty adults (18-56 years old) participated in this study without any cardiovascular disease, hypertension, and contraindication for cupping. There were two groups (15 participants each): the sunnah group undergoing wet cupping on the $17^{\text {th }}, 19^{\text {th }}$, and $21^{\text {st }}$, and the nonsunnah group undergoing wet-cupping on the $18^{\text {th }}, 20^{\text {th }}$, and $22^{\text {nd }}$ of the Islamic Calendar. Result: The result showed a significant difference between the sunnah and non-sunnah groups for the diastole group $(P=0.00)$. However, there were no significant differences for systole $(P=0.65)$, heart rate $(P=0.77)$, respiratory rate $(P=0.13)$, and temperature $(P=0.51)$. Conclusion: There are potential differences in cupping therapy's efficacy on vital signs between sunnah and non-sunnah dates. Future research needs to study more with patients as participants and a greater sample size.
\end{abstract}

Keywords: Islamic Wet Cupping Therapy, Vital Sign, Lunar Phase, Sunnah Date

\section{INTRODUCTION}

Wet Cupping Therapy is a treatment method by suctioning the skin in certain parts to remove toxins and oxidants accumulated in the body through capillaries in the epidermis $[1,2]$. Traditionally, cupping has been practiced in several primary world cultures for centuries. Cupping in Arabic is known as Al-Hijama, which means "to return the body to its original state." In other words, Hijama refers to balancing bodily humor [3]

Cupping is the best treatment solution for every Muslim because Rasulullah SAW said: "It is good that the treatment you are doing is Al Hijamah" (HR. Ahmad) [4]. Scientifically, cupping can be used as a preventive, curative, and rehabilitative effort. Cupping reduces cardiovascular disease risk and treats various diseases such as hypertension, migraine, carpal tunnel syndrome, stroke rehabilitation, and effectively influencing the autonomic system [5-8] [9, 10].

The best time to do cupping is after the full moon; Rasulullah SAW said: "Whoever does cupping on the $17^{\text {th }}, 19^{\text {th }}$, or $21^{\text {st }}$ day will cure various diseases" (HR Abu Dawud) [4]. The author of a book entitled AlQanoon, Sina [1] (980-1037 BC) said: "Cupping is not preferred at the beginning or end of the month.
Preferably in the middle of the month when the toxic substances in the body accumulate". This condition happens because of the relationship between the phases of the moon phase and the human body's condition.

The moon phase can affect the heart's performance, blood flow, and the human hormonal system [11] [12] [9]. Besides, there is an increase in sudden death in epilepsy, acute behavioral disorders, non-affective psychotic disorders, depression, gastrointestinal bleeding, and acute myocardial infarction during the full moon. Spontaneous abortion and atrial fibrillation attacks may also be associated with the moon phase [13].

Benli \& Sunay concluded that cupping is more effective in treating migraines when it is done after the 14th (Islamic calendar or called Hijrah) or after the full moon phase (FM) [9]. After the full moon phase, two other moon phases, are the Third Quarter (TQ) and the Waning Gibbous (WB) phase, are between the TQ and FM phases. The FM phase occurs on day 14, the WB phase on day 17, and the TQ phase on day 21 [12].

Based on this description, the sunnah dates of cupping $\left(17^{\text {th }}, 19^{\text {th }}\right.$, and $\left.21^{\text {st }}\right)$ is in the moon phase of WB and ends in the TQ phase, which is proven to be useful in cupping applications. However, apart from the sunnah dates, there 
are other dates after the $14^{\text {th }}$, which may also be useful in cupping applications. There have been no studies comparing the effectiveness of cupping on the sunnah dates with other dates between the moon phases of WB and TQ.

\section{METHOD}

\subsection{Research Design}

This research was a quantitative study with a quasiexperimental approach, with two treatment groups. The two groups are the cupping group on the sunnah and the cupping group on the non-sunnah. It was conducted between July-September 2020. This research received ethical acceptance by the ethics commission of Universitas 'Aisyiyah Yogyakarta with number 1678/KEP-UNISA/VIII/2020.

\subsection{Participants}

The participants of this study consisted of 30 adults who used cupping therapy services. This study involved adult participants in the age range of 18-56, who did not have cardiovascular disease or hypertension and had no contraindications for cupping. There were two groups (15 participants each): the sunnah group undergoing wet cupping on the $17^{\text {th }}, 19^{\text {th }}$, and $21^{\text {st }}$, and the non-sunnah group undergoing wet-cupping on the $18^{\text {th }}$, $20^{\text {th }}$, and $22^{\text {nd }}$ of the Islamic Calendar (Hijri month).

\subsection{Intervention}

The first group was given cupping therapy on the sunnah's dates; the $17^{\text {th }}, 19^{\text {th }}, 21^{\text {st }}$ of the Hijri month. The other group was cupped on the non-sunnah dates; $18^{\text {th }}$, $20^{\text {th }}$, and $22^{\text {nd }}$ of the Hijri month. Both of the date groups were still in the TQ and FM phases or called WB.

The cupping therapy in this study used Cupping Puncture Cupping (CPC) method. Firstly, the therapist cleaned the cupping point area using alcohol and then cupped the cupping point. The first vacuuming lasted for 5 minutes, levitating the cup slowly. It was then stabbing the point area with 20 needle pricks (Puncturing step) that put back the cup for the second vacuuming step for 7 minutes. In the end, the therapist took the cup slowly while cleaning the blood from the point area and the cup. Then he applied olive oil on the point area.

The cupping applied on three cupping points consisted of 2 points on the back neck area around the sternocleidomastoid muscle, called Al Akhda'in. The other point was located around Processus spinosus vertebrae cervical VII called Al Kahil. Those three points are Islamic cupping recommended points literally.

\subsection{Outcome Measure}

The examination measured out on the participants before and after therapy examined vital signs, including blood pressure (systole and diastole), heart rate, respiratory rate, and temperature.

\subsection{Statistic Analysis}

Statistical analysis was performed using SPSS, version 16.0. Comparison between two groups by the Independent T-test and Mann-Whitney $\mathrm{U}$ test. $\mathrm{P}$ values $<0.05$ were considered significant.

\section{RESULT}

Table 1. shows the characteristic of participants with $10(66.67 \%)$ males and $5(33.33 \%)$ females for both groups. There is three age range of participants. For 18 35 years old, there are $10(66.67 \%)$ participants in both groups. There are $5(33.33 \%)$ participants in the sunnah group and $4(26.67 \%)$ participants in the non-sunnah group for 36-55 years old. For 56-74 years old, 1 (6.66\%) participant is only in the non-sunnah group.

Table 2 . shows the data analysis started by normality test in statistical. This study found a significant difference between the mean of diastolic in the sunnah and nonsunnah group with $P=0,00$. However, there are no significant differences for systole $(P=0.65)$, heart rate $(P=0.77)$, respiratory rate $(P=0.13)$, and temperature $(P=0.51)$.

\section{DISCUSSION}

Participants' characteristics showed equality in the number of genders (10 males and 5 females) in both groups. The purpose is to minimize bias for the result due to the gender issue. The range of age was divided into three classifications; young adult (18-36), mid-adult (3755), and late-adult (56-74). Most participants in this study were in the young adult age range.

\subsection{Cupping therapy effect on systole}

The results showed no significant difference in systolic blood pressure $(P=0.65)$ between the sunnah and non-sunnah groups. This result happened because both groups experienced a decrease in systolic blood pressure after cupping. The drop in blood pressure in both groups was probably related to the moon phase.

This study is consistent with previous studies on the relationship between moon phases and blood pressure [12]. The full moon phase could affect the heart's performance, blood flow, and the human hormonal system [11, 12] [9]. This condition occurred because the effect of the magnetic field and the intensity of moonlight during the full moon directly affected the levels of the hormone melatonin in the blood [14] [15] [16]. Although the sunnah's and non-sunnah dates are different, both are included in the same moon phase. They are between the FM and TQ moon phases.

The insignificant difference between two groups is because the sample in this study was participants with 
typical vital signs. The drop in blood pressure was still within normal limits due to the small number of samples. Thus, this study cannot generalize that there is no difference in the effect of cupping on the sunnah and nonsunnah dates.

\subsection{Cupping therapy effect on diastole}

The results showed a significant difference $(P=0,00)$ between diastolic blood pressure in the sunnah and non- sunnah groups. The difference in diastolic blood pressure may also be related to the timing of cupping. This result follows studies conducted by Aleyeidi, Aseri, and Kawthar, which reported that cupping did not positively affect blood pressure when done on non-sunnah dates [17].

Table 1. Characteristics of Participants

\begin{tabular}{|c|c|c|}
\hline Category & Sunnah $(n=15)$ & Non-sunnah $(n=15)$ \\
\hline Gender & & $10(66.67 \%)$ \\
\hline Male & $10(66.67 \%)$ & $5(33.33 \%)$ \\
\hline Female & $5(33.33 \%)$ & $10(66.67 \%)$ \\
\hline Age & & $4(26.67)$ \\
\hline $18-35$ & $10(66.67 \%)$ & $1(6.66)$ \\
\hline $36-55$ & $5(33.33 \%)$ & 1 \\
\hline $56-74$ & - & \\
\hline
\end{tabular}

Table 2. Comparison between sunnah and non-sunnah group

\begin{tabular}{|c|c|c|c|}
\hline \multirow[b]{2}{*}{ Variable } & \multicolumn{2}{|c|}{ Mean \pm SD } & \multirow[b]{2}{*}{$P$-value } \\
\hline & Sunnah $(n=15)$ & Non-sunnah $(n=15)$ & \\
\hline Systole & $116.20 \pm 10.34$ & $117.86 \pm 9.62$ & 0.65 \\
\hline Diastole & $77.20 \pm 10.50$ & $79.26 \pm 7.75$ & $0.00 *$ \\
\hline Heart rate & $77.46 \pm 11.29$ & $78.60 \pm 10.11$ & 0.77 \\
\hline Respiratory Rate & $18.86 \pm 3.31$ & $20.13 \pm 3.66$ & 0.13 \\
\hline Temperature & $36.56 \pm 0.35$ & $36.58 \pm 0.23$ & 0.51 \\
\hline
\end{tabular}

In contrast, cupping reduced systolic blood pressure in hypertensive patients when done on the sunnah dates [18]. Lowering systolic blood pressure can be explained by the Taibah Theory by releasing CPS (causative pathological substance), interstitial fluid, old/damaged erythrocytes, hydrophilic and hydrophobic materials in the form of lipoproteins that occur during the cupping process [19].

\subsection{Cupping therapy effect on heart rate}

This study compared two groups and then found that participants' heart rate in the two intervention groups was not statistically different $(P=0.77)$. It means that cupping therapy in sunnah dates and nonsunnah dates have a similar effect on heart rate. Some studies showed that the lunar cycle could influence humans' physical health profile, including heart rate. This finding is in line with the previous study mentioning that cupping therapy could not change the heart rate baseline [20]. A specific study of the physical fitness index, heart rate, and blood pressure in different phases of the moon cycle found that heart rate was not different between each phase [12].
The single applying of cupping without timing consideration was believed to decrease the heart rate [21]. A previous study also found that cupping had a more substantial impact on reducing the heart rate than spot massage therapy. Reducing the heart rate was believed to affect muscle relaxation and dilatation of blood vessels, decreasing blood pressure [22]. Further investigation on the cupping effect on heart rate should be conducted in a more significant number than the recent study.

\subsection{Cupping therapy effect on Respiration Rate}

The result showed that the significant value from the mean comparison of the two groups was no statistically different $(P=0.13)$. However, it cannot be defined as no effect of cupping therapy on the respiration aspect. Based on an earlier study, cupping therapy was significantly increasing the respiratory exchange ratio [23]. Cupping therapy also effectively improved the pulmonary functions in asthmatic children with mild asthma [24]. 
The moon cycle trusts have a gravitational impact when the ocean tides. It could affect the human body, such as respiratory conditions [25]. However, a recent study could not conclude any difference between the respiratory rate in two groups within days after the full moon phase. A low number of participants might lead to limitations of analysis results. Future studies should recruit more individuals as part of the study.

\subsection{Cupping therapy effect on temperature}

Temperature is a vital sign that needs to be monitored during patient care [26]. In this study, the researchers observed changes in patient temperature after cupping. The results showed no significant difference $(P=0.51)$ between temperature in both groups after cupping was made.

This result follows a study conducted by Volpato et al. There was no significant difference in temperature before, after, and one week after cupping [27]. However, this result is different from previous studies, reporting that negative pressure during cupping would increase the cupping area's temperature [28]. The previous study also explained that pressure and the length of the cupping time might be a factor in the increase in temperature throughout the body.

Therefore, there was no significant difference in body temperature after cupping. This result may be due to several factors, including the length of time to vacuum and the strength of the negative pressure exerted during cupping.

\section{CONCLUSION}

There are potential differences in cupping therapy's efficacy on vital signs between sunnah and non-sunnah dates. More studies are needed to explore wet cupping's comparative effectiveness between sunnah and nonsunnah date in patients with a greater sample size.

\section{AUTHORS' CONTRIBUTIONS}

All authors conceived and designed the study. SS and NR collected and analyzed the data while AS prepared the respondent and conducted the experiments. All authors wrote, read, and approved the manuscript.

\section{ACKNOWLEDGMENTS}

The authors would like to thank all participants for their participation in this study and the Faculty of Medicine and Health Sciences, Universitas Muhammadiyah Yogyakarta, for this project's financial support.

\section{REFERENCES}

[1] Sina, I.: 'Alqanoon Fil Tib (English translation by Mazhar H. Shah)', New Delhi: Idara kitab us Shifa, 2007, 279

[2] Ridho, A.A.: 'Bekam Sinergi (Edisi Penyempurnaan)', Solo: Aqwamedika, 2015

[3] Sheikho, M.A., and Al-Dayrani, AKJA: 'Cupping: a prophetical medicine appears in its new scientific perspective' (BookRix, 2015. 2015)

[4] Al-Bukhari, MI: 'The English Translation of Sahih Al Bukhari with the Arabic Text (9 Volume Set)', Translated by Muhammad Muhsin Khan, AlSaadawi Publications, 1996

[5] Hasan, I., Ahmad, T., and Ahmad, S.: 'Management of hypertension by wet cupping therapy (Al-Hijamah): a case study,' Int J Pharmacol Toxicol, 2014, 4, (1), pp. 24-27

[6] Hanan, S., and Eman, S.: 'Cupping therapy (alhijama): Its impact on persistent non-specific lower back pain and client disability,' Life Sci J, 2013, 10, (4), pp. 631-642

[7] Refaat, B., El-Shemi, A.G., Ebid, A.A., Ashshi, A., and BaSalamah, M.A.: 'Islamic wet cupping and risk factors of cardiovascular diseases: effects on blood pressure, metabolic profile and serum electrolytes in healthy young adult men,' Altern Integ Med, 2014, 3, (1), pp. 151

[8] Lee, M.S., Choi, T.-Y., Shin, B.-C., Han, C.-h., and Ernst, E.: 'Cupping for stroke rehabilitation: a systematic review,' Journal of the neurological sciences, 2010, 294, (1-2), pp. 70-73 https://doi.org/10.1016/j.jns.2010.03.033

[9] Benli, A.R., and Sunay, D.: 'Changing efficacy of wet cupping therapy in migraine with lunar phase: A self-controlled interventional study,' Medical science monitor: international medical Journal of experimental and clinical research, 2017, 23, pp. 6162 https://doi.org/10.12659/MSM.905199

[10] Syahruramdhani, S., Agustiningsih, D., and Sofro, Z.M.: 'The Influence of Dry Cupping toward Heart Rate Variability (HRV) in Male Obesity adolescence,' Mutiara Medika: Jurnal Kedokteran dan Kesehatan, 2016, 16, (2), pp. 71-75

[11] Şeker, N.: 'Prophet and preventive medicine: The case of bloodletting,' The University of Kahramanmaras Sutcu Imam Review of the Faculty of Theology, 2013, 21, pp. 157-187

[12] Chakraborty, U., and Ghosh, T.: 'A study on the physical fitness index, heart rate and blood pressure in different phases of lunar month on male human subjects,' International Journal of biometeorology, 2013, 57, (5), pp. 769-774 https://doi.org/10.1007/s00484-012-0605-z

[13] Bevington, M.: 'Lunar biological effects and the magnetosphere,' Pathophysiology, 2015, 22, (4), pp.

211-222 https://doi.org/10.1016/j.pathophys.2015.08.005

[14] Takemura, A., Ueda, S., Hiyakawa, N., and Nikaido, Y.: 'A direct influence of moonlight 
intensity on changes in melatonin production by cultured pineal glands of the golden rabbitfish, Siganus guttatus,' Journal of Pineal Research,
2006,
40 ,
(3),
pp.
236-241

https://doi.org/10.1111/j.1600079X.2005.00306.X

[15] Oliveira, C., Duncan, N.J., Pousão-Ferreira, P., Mañanós, E., and Sánchez-Vázquez, F.J.: 'Influence of the lunar cycle on plasma melatonin, vitellogenin and sex steroids rhythms in Senegal sole, Solea senegalensis,' Aquaculture, 2010, 306, (1-4), pp. 343-347 https://doi.org/10.1016/j.aquaculture.2010.05.003

[16]Zimecki, M.: 'The lunar cycle: effects on human and animal behavior and physiology Cykl księżycowy: wpływ na zachowanie ludzi i zwierząt i ich fizjologię,' Postepy Hig Med Dosw. (online), 2006, 60, pp. 1-7

[17] Aleyeidi, N., Aseri, K., and Kawthar, A.: 'The efficacy of wet cupping on blood pressure among hypertension patients in Jeddah, Saudi Arabia: A randomized controlled trial pilot study,' Altern Integr Med, 2015, 4, pp. 183 https://doi.org/10.4172/2327-5162.1000183

[18] Aleyeidi, N.A., Aseri, K.S., Matbouli, S.M., Sulaiamani, A.A., and Kobeisy, S.A.: 'Effects of wet-cupping on blood pressure in hypertensive patients: a randomized controlled trial,' Journal of integrative medicine, 2015, 13, (6), pp. 391-399 https://doi.org/10.1016/S2095-4964(15)60197-2

[19] El Sayed, S.M., Mahmoud, H.S., and Nabo, M.M.H.: 'Methods of wet cupping therapy (AlHijamah): in light of modern medicine and prophetic medicine,' Alternative \& Integrative Medicine, 2013, pp. 1-16 https://doi.org/10.4172/2327-5162.1000111

[20] Shekarforoush, S., Foadoddini, M., Noroozzadeh, A., Akbarinia, H., and Khoshbaten, A.: 'Cardiac effects of cupping: myocardial infarction, arrhythmias, heart rate and mean arterial blood pressure in the rat heart,' Chin J Physiol, 2012, 55, (4), pp. 253-258

[21] Ningsih, Y.F.: 'Pengaruh Sport Massage dan Terapi Bekam Terhadap Penurunan Kadar Asam Laktat dan Denyut Nadi,' Journal of Physical Education Health and Sport, 2016, 3, (2)

[22] Lestari, YA, Hartono, A., and Susanti, U.: 'Pengaruh Terapi Bekam Terhadap Perubahan Tekanan Darah Pada Penderita Hipertensi Di Dusun Tambak Rejo Desa Gayaman Mojokerto,' Nurse and Health: Jurnal Keperawatan, 2017, 6, (2), pp. 14-20 https://doi.org/10.36720/nhjk.v6i2.16

[23] Antush, M.: 'Effect of Cupping Therapy on Respiratory Gas Exchange in Trained Endurance Runners,' 2019

[24] 洪佳璇, 傅明丽, 王肖原, and 高智凤: 'Effects of cupping therapy on the pulmonary functions in asthmatic children,' 中医杂志: 英文版, 2006, 26, (1), pp. 7-7

[25] Kan, HOBAF: 'The Effect of the Phases of the Moon on Blood Pressure in Non-Hypertensive Individuals'

[26]Elliott, M., and Coventry, A.: 'Critical care: the eight vital signs of patient monitoring,' British Journal of Nursing, 2012, 21, (10), pp. 621-625 https://doi.org/10.12968/bjon.2012.21.10.621

[27] Volpato, M.P., Breda, I.C.A., de Carvalho, R.C., de Castro Moura, C., Ferreira, L.L., Silva, M.L., and Silva, J.R.T.: 'Single Cupping Therapy Session Improves Pain, Sleep, and Disability in Patients with Non-specific Chronic Low Back Pain,' Journal of acupuncture and meridian studies, 2020, 13, (2), pp. 48-52 https://doi.org/10.1016/j.jams.2019.11.004

[28] Duh, F.-C., and Chiu, Y.-H.: 'Vacuum cupping under various negative pressures: An experimental investigation,' Vacuum, 2015, 2, (7) 